\title{
Developing rural tourism in minority ethnic villages: Zlot and Xiaocang She Ethnic Township
}

\author{
Marko Blažević ${ }^{1 *}$, Katarina Peters ${ }^{2}$, Guisong Chen ${ }^{1}$ \\ ${ }^{1}$ Fujian Agriculture and Forestry University, College of Management/College of Tourism \\ ${ }^{2}$ University of Belgrade, Faculty of Philology
}

\begin{abstract}
This paper deals with deploring two villages, one in Europe in the eastern part of Serbia called Zlot village and one in China in Fujian province by the name of Xiaocang She Ethnic Township. These two villages have a significant population of national minorities, so their historical backgrounds and local traditions are explained in order to point to their potential of development as rural tourist destinations. Using the empowerment model, the villages can develop and reach their full potential. Provide their residents with better income and incentive to keep and share invaluable minority traditions that have been alive for a long period of time. The empowerment model can help locals improve their economic status by being involved in tourism in their respective villages. Due to the rich local traditions of the minorities living there and beautiful natural scenery, tourism potential is vast. Langde Mode should be implemented in a way of community guidance in order to improve both, rural tourism in these areas, as well as the lives of the local community.
\end{abstract}

Keywords: empowerment, rural tourism, minority culture, Zlot village, Xiaocang She Ethnic Township

JEL classification: Z32

\section{Razvoj turizma u selima sa kulturama manjina: selo Zlot i selo Sjaocang Še naroda}

Sažetak: Ovaj rad istražuje dva sela, jedno u Evropi u istočnom delu Srbije po imenu Zlot, a drugo u Kini u provinciji Fuđen, selo Sjaocang Še naroda. Ovo su dva sela sa značajnom populacijom nacionalnih manjina, pa je njihova istorijska pozadina i lokalna tradicija objašnjena kako bi se ukazalo na potencijal za razvoj seoskog turizma. Pomoću modela osnaživanja stanovništva, sela se mogu razviti i dostići svoj puni potencijal kao i pružiti svojim stanovnicima bolje prihode i podsticaj da zadrže i podele sa drugima vredne tradicije manjina, koje postoje već dugi niz godina. Model osnaživanja može pomoći lokalnom stanovništvu u poboljšanju ekonomskog statusa tako što će biti uključeni u turizam u svojim selima, a zbog bogate lokalne tradicije manjina koje tu žive i prekrasnog prirodnog krajolika potencijal je veliki. Langde Mode bi se trebalo sprovesti tako što će davati smernice zajednici kako bi se poboljšao seoski turizam na ovim područjima, kao i život lokalne zajednice.

Ključne reči: osnaživanje stanovništva, seoski turizam, kulture manjina, selo Zlot, selo Sjaocang Še naroda

JEL klasifikacija: Z32

*markoblaz@live.com 


\section{Historical background of Zlot village}

Zlot is a village which is a part of Bor municipality located in the eastern part of Serbia. It is not certain how this village got its name. One of the possibilities is that name came from Polish currency which is called Złoty, since lots of coins of Złoty have been found in this area. They are believed to have arrived in Serbia during some of the migrations and the Serbian spelling of this currency is Zlot. This village is positioned at the foot of Malinik Mountain and the Zlotska River. It is a mountainous village with the highest peak being $1,284 \mathrm{~m}$ above sea level. According to the area $\left(229,867 \mathrm{~km}^{2}\right)$ as well as population $(3,299$ people, in total 1,005 households as of 2017) Zlot is not only the biggest village in Bor municipality but also one of the biggest villages in Timočka Krajina region of Serbia.

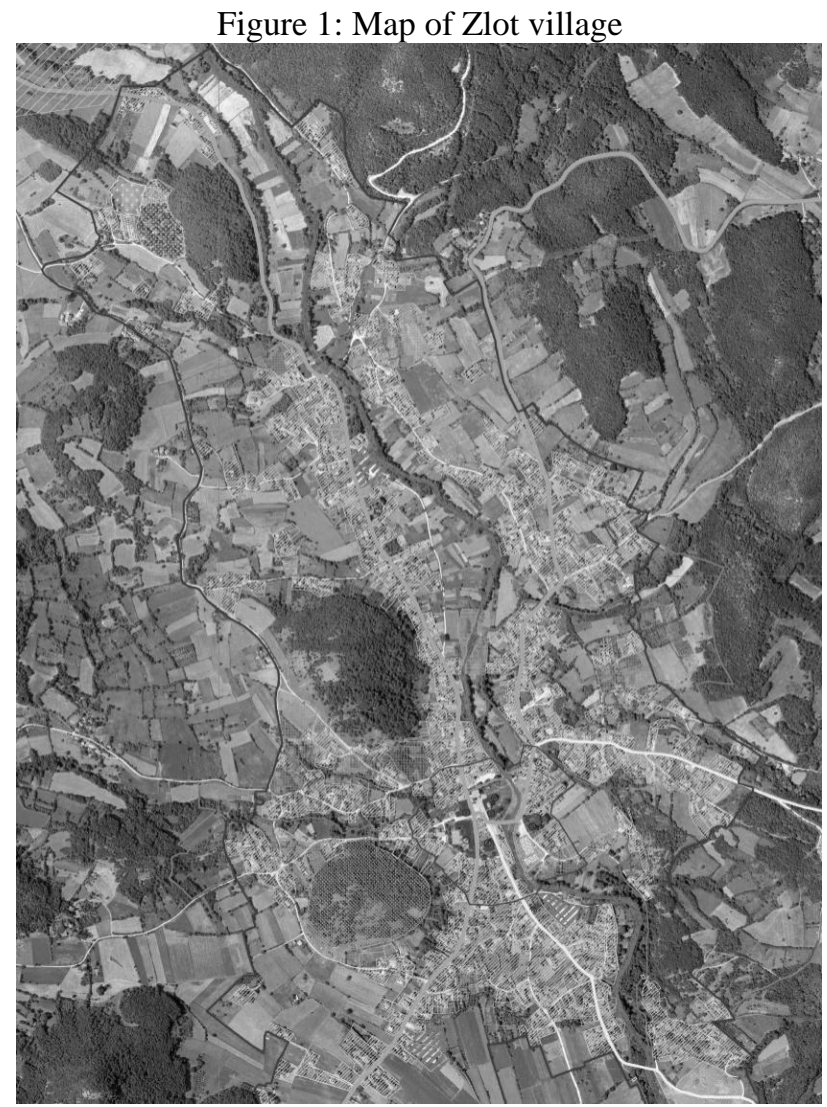

Source: Author, 2018

Also is one of the most beautiful ones. Near the village there is the longest explored cave in Serbia with the name Lazareva Pećina, sometimes also referred to as Zlotska Cave. There are two stories where the name of the cave might be coming from. The first one comes from the story about prince Lazar of Serbia and his army that after the Battle of Kosovo, where Lazar was killed, were hiding in the cave. The second story is connected with Hajduk Lazar, an outlaw who stole a vast fortune from the Turks in Ottoman Serbia and hid it inside this cave. The fortune is still believed to be hidden inside of the cave. According to the "2012's Recent Landform Evolution: The Carpatho-Balkan-Dinaric Region", the cave is 9,407 meters long. The cave is situated near the entrance of the deep canyon carved into the mountains by the Zlotska River. The cave has been popular for tourism since at least the 19th century when it was one of the three most popular caving destinations in Serbia along with Prekonoska and 
Petnicka. There are around 116 caves but some are still not discovered so this number could go up in the future. Some of the paths are illuminated and tourist services are offered for modern visitors. It has been protected since 1949. Besides the caves, one of the best sceneries here is the view over the Zlotska River from Lazar's Gorge, which is truly a spectacular view. Lazar's Gorge was declared a geo-park of Serbia in 2005. Zlot village and its surroundings are considered one of Serbia's best eco-tourism destinations.

\section{Local traditions of Zlot village}

Besides having good natural resources, which are the base for being an attractive tourist spot, Zlot village also has interesting demographics. Demographics of the village are as follows: the Serbs $(72,89 \%)$, the Vlachs $(13,78 \%)$, the Romani people $(3,61 \%)$ and others $(1,91 \%)$. Even though the Serbs are the majority population, this village and the whole eastern part of Serbia are very influenced by the traditions of the Vlachs, which are the largest minority in this area as well as in Zlot. The Vlachs are an ethnic minority who inhabit eastern part of Serbia and they are culturally and linguistically related to Romanians: they speak the dialects similar to ones in parts of western Romania that belong to a completely different language family from a Serbian and have a distinct local customs and traditions. Historically speaking, the Vlachs have never had their own country and today they live in five of the Balkan Peninsula countries (Greece, Albania, Macedonia, Serbia and Bulgaria), as well as in Romanian Dobrogea (Nowicka, 2016). This minority is highly assimilated into Serbian society, many of them are even considering themselves Serbs that speak the Vlach language, are bilingual in Serbian and Vlach languages, and adhering to the Eastern Orthodox Church, a religion which most Serbs are a part of. Having been highly assimilated into Serbian society did not affect Vlachs retaining their own culture and local traditions. Ethno-social values of the Vlachs can be seen as an authentic touristic product, only people with their cultural background can offer (Trišić, 2017).

Figure 2: Vlachs performing a traditional folk dance in traditional clothing

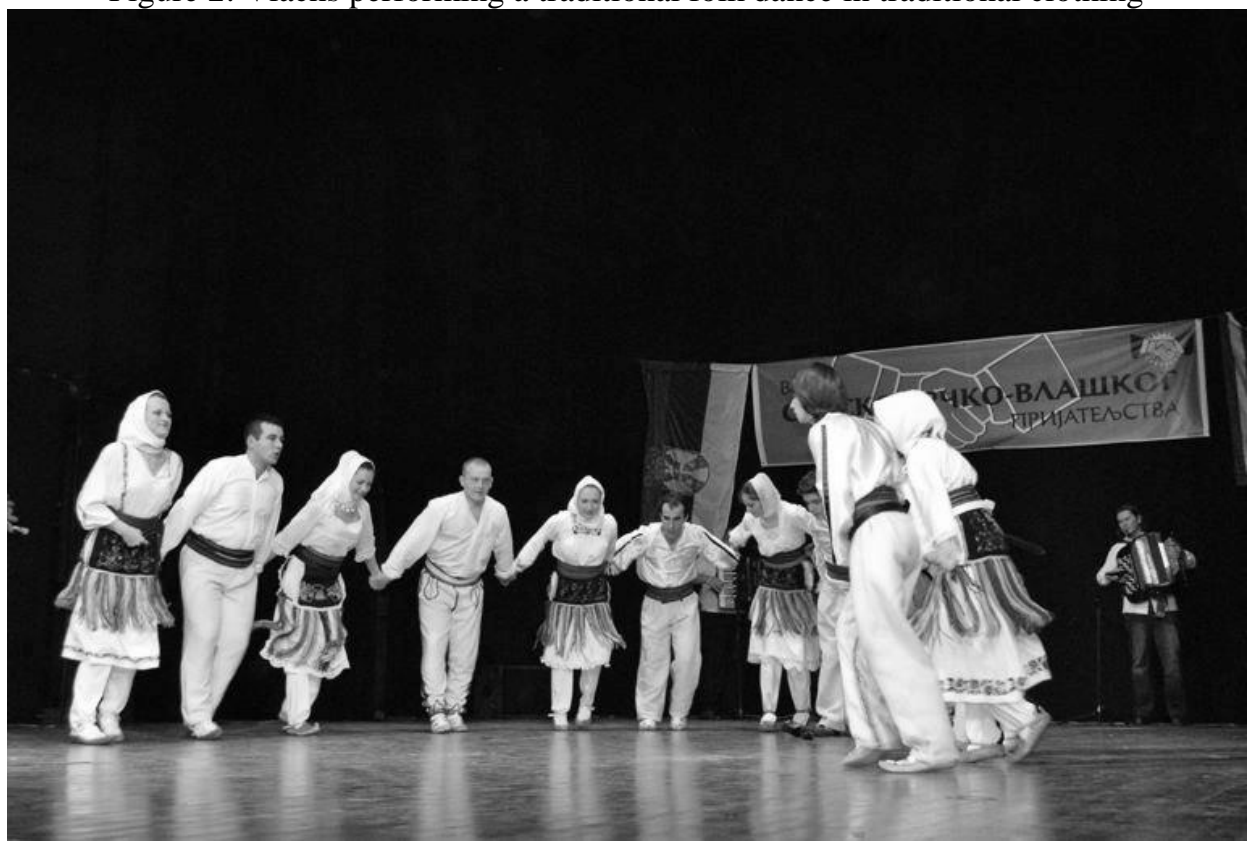

Source: Kud Petar Radovanović Zlot, 2013 
Local traditions of the Vlachs have been attracting visitors for a long time. They are famous for performing a different kind of rituals for which they believe to have magic effects. In addition to mostly being Orthodox Christians, the Vlachs still keep on to some pagan customs, pre-Christian, Indo-European and Paleo-Balkan elements and so-called "white" and "black" magic. The spirituality this minority group poses is unique and one of the oldest ones in Europe. People from all around Serbia and Europe visit areas where the Vlachs live so they can use the power of their supposed magical talents (Ivkov-Džigurski et al., 2012). Besides these rituals, they also have different kinds of festivals. One of them is roughly translated as "Villages meet" where different villages with Vlach population compete with various performances: dancing, singing, recitals, performing different kinds of traditional performances. One of biggest festivals in eastern Serbia occurs in Zlot and attracts a lot of curious visitors.

\section{Historical background of Xiaocang She Ethnic Township}

Xiaocang She Ethnic Township is Fujian province's oldest Ethnic Township. The village is located in Lianjiang County in the northwest of Aojiang in the middle reaches of the east side of the river. It is 48 kilometers from the city center of Fuzhou and 53 kilometers from Lianjiang County.

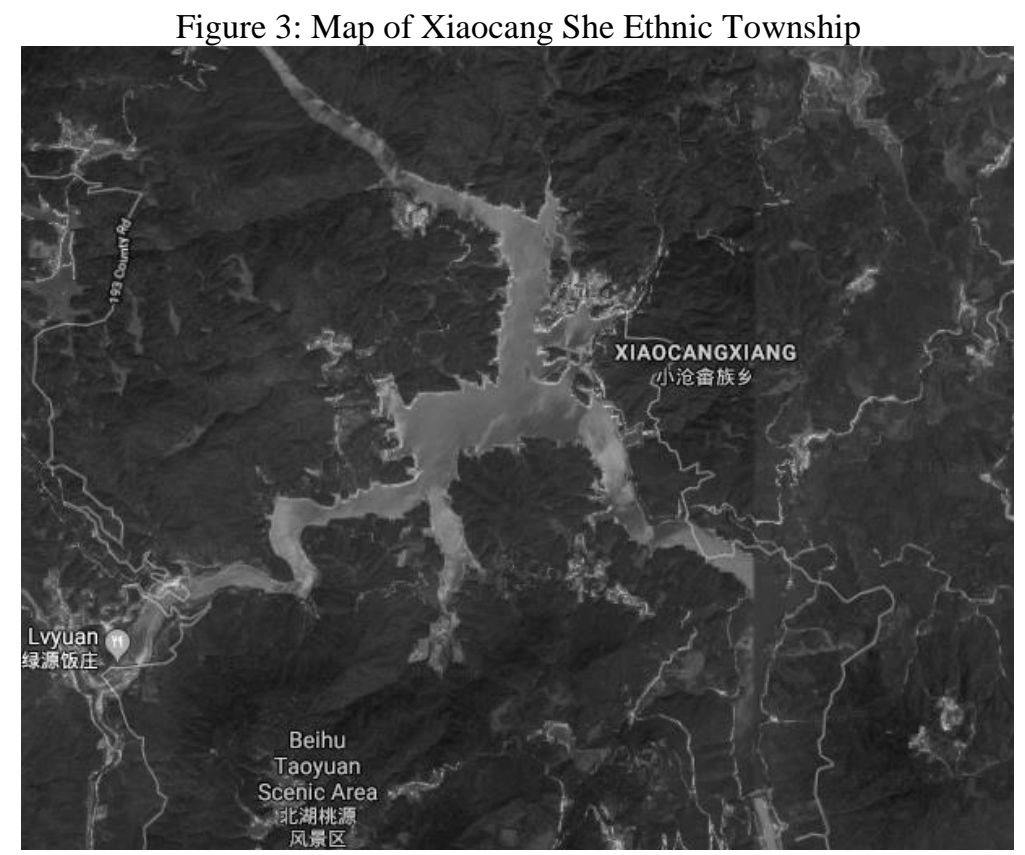

Source: Author, 2018

Tourism is an emerging industry in this village. Held since 2000 the "March three" black rice Festival, since the official opening of Yu Lake folk customs tour, received a total of more than 60 thousand tourists outside the province, a social output value of about 3,000,000 $\mathrm{RMB}$, to promote the development of shipping, commerce, catering, planting and breeding industry. There are around 850 households in Xiaocang She Ethnic Township, with a total population of 4,073 people and distributed in 18 natural villages, with a total of 5 villagers committees and 38 villager groups. The total land area of the township is 60.4 square kilometers. 


\section{Local traditions of people in Xiaocang She Ethnic Township}

As the name of this village says, it is a place with a strong influence of She Ethnic minority, a Chinese ethnic group, one of the 56 officially recognized by the People's Republic of China. They call themselves 'Hill visitors' or 'Shanha', which means they are visitors, but not native people to this area. The She is the largest ethnic minority in Fujian province. They are also present in the provinces of Zhejiang, Anhui, Jiangxi and Guangdong. Some descendants of the She also exist amongst the Hakka minority in Taiwan. During the Ming-Qing dynasties, they moved to and settled in the southern region of Zhejiang province and mountain districts in the Lower Yangtze region after they left their homeland in Northern Fujian province. It is theorized that the She were pushed out of their land by the Hakka, which caused them to move into Zhejiang, but a sizable amount of the She people are still living in Fujian province. They speak Shehua, an unclassified Chinese variety that has been heavily influenced by Hakka Chinese and they have their own traditions which are being kept until this day. Folk music is an essential part of She nationalities' culture which is performed during marriage ceremonies, traditional festivals and even when they are working in the field. "Three March" is a traditional festival of the She nationality. It is held every year the third day of the third month of the Chinese lunar calendar.

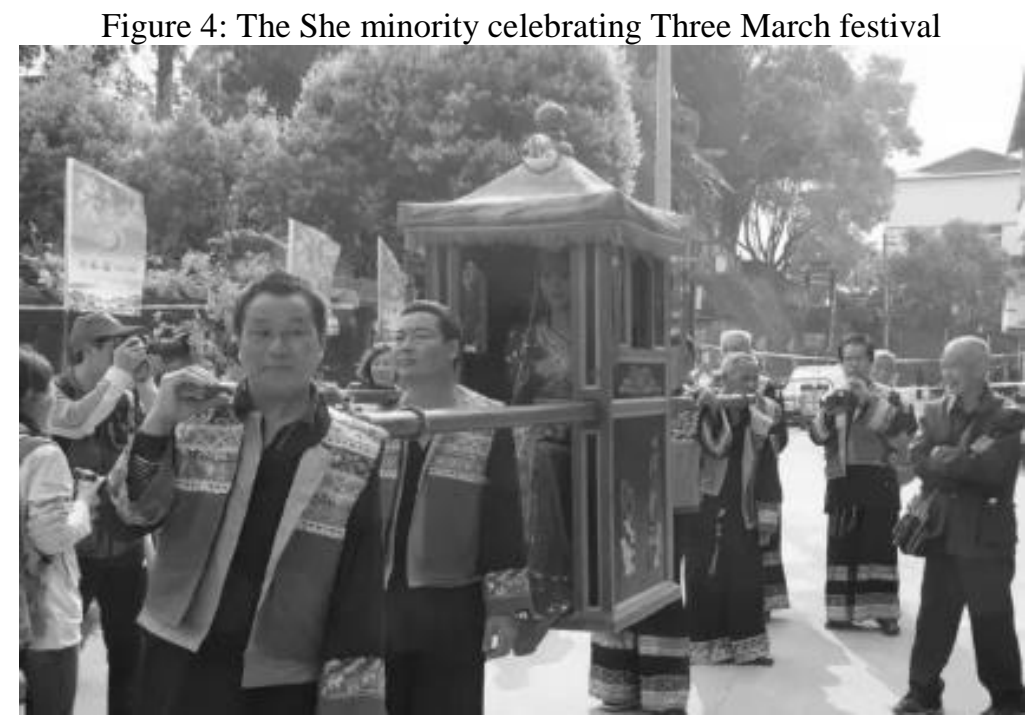

Source: Author, 2018

Its main activity is to go outside and eat black rice as to remember the ancestors, so this festival is also known as the "black rice Festival". In Tang Dynasty, the leaders of the She nationality, Lei Wanxing and Lan Feng, led the people of the She nationality to resist the ruling class at the time and were besieged by the Imperial Army on the mountain. To commemorate these solders people take March 3rd as a festival and eat "rice" to commemorate them. During the festival, dozens of families gather to celebrate, which attracts tourists to observe their traditional local customs. Today, She marital customs are much like those of the Hans. But under pre-1949 feudal conditions, parent-arranged marriages were common, as were outright sales of daughters. Brides' dowries usually included farm tools, bamboo hats and rain capes. The wedding ceremony was simple. The groom would go to the home of the bride's family for a feast. Finding the table empty, he would sing out what he wanted, calling for chopsticks, wine and traditional wedding food. At the end of the banquet, he would sing again, this time ordering the dishes to be removed. The 
cook in return would sing his songs with melodies of his own. The newlyweds would say prayers to their ancestors and bid farewell to the bride's relatives. With the groom in front, they would walk to his family's home, each holding an umbrella and singing in echo. The groom's parents would welcome them at the front door, completing the wedding ceremony. As the feudal landlord system evolved, parents and matchmakers became more important in making "correct" marriages; bride prices became exorbitant, and the poorest peasants were unable to afford marriage. Because of so many pre-arranged, loveless marriages, folk singing gatherings became a means for people to spend time with their lovers -- in defiance of the feudal marriage system.

\section{Literature review}

\section{Rural tourism - an effective approach for revitalizing villages}

In recent years tourism has become an important part of economies in many countries so scholars all over the world have been putting a focus on researching it. A big part of tourism, rural and eco-tourism have been emerging as a way for revitalizing villages, getting an infusion of money into the budget and offering tourists a completely different tourist experience. Rural tourism is one of the forms of tourism that incorporates aspects of sustainable development, environmental protection, development of entrepreneurship, both in direct activities and those related to the practice of this form of tourism traditions and customs, ancient and unspoiled (Balan \& Burghelea, 2015).

Villages which are historically and culturally significant have an even better chance of success in tourism since tourists are quite interested in exploring different local customs and traditions. Rural tourism has been recognized as a tool for poverty reduction, but its effects on locals are still being discussed by scholars. Even there is a possibility that rural tourism is affecting locals in a negative way. Still, it is used by lots of governments as a way of improving the way of life of the locals. The most effective method of including locals in rural tourism is community participation or community-based action. A good partnership between village residents and outside developers would lead to sustainable dialogue for the growth of tourism and would also help the village residents (Gao \& Wu, 2017) as where some authors put forward the connections between rural tourism and traditional ethnic identity which is being stringent by rural tourism and wish to preserve and present own culture and traditions (Silva \& Lenar, 2015). Rural tourism in China has started developing quite late in comparison with the rest of the world but nowadays it has taken the primate due to the changing interest of the tourists (Guo \& Sun, 2016). However, rural tourism is not in its beginnings only in China; in Serbia, rural tourism is at its infancy stage as well (Dimitrovski et al., 2012).

\section{The empowerment of Zlot and Xiaocang village}

Both of these villages even though in different continents have more than one similarity: minority culture is visible, and with good natural resources make a perfect combination for a good rural tourist destination. But even with these good conditions for making a good rural tourist destination they still have not reached their full potential. Better promotion of these villages and putting forward their special minority cultures would attract a lot of new tourists. It is not being said that now tourists are not visiting these villages but with better marketing, they have a potential of being leading ethnic rural tourist destinations in their regions. Following the example of some of the successful ethnic rural destinations, they can improve their facilities and offer tourists a completely new experience incorporating rural tourism, eco-tourism with the elements of the minority cultures, festivals and customs being 
both educational and fun. One of the successful examples which can be followed is Langde Miao minority village in Kaili, Guizhou province, China characterized by community guidance, public participation, and its work point system is known as the "Langde Mode" (Chen et al., 2016). Authors, Chen, $\mathrm{Li} \& \mathrm{Li}$, in their paper explore empowerment of the villages as a great model of how to help locals and develop rural tourism in minority rural villages. But this is not the first time the empowerment models have been used in China. They were mentioned for the first time by Zuo (2009) and have been used in China for almost a decade now. This model can also be adopted by Zlot village in Serbia and Xiaocang village in Fujian, China, and help them improve their positioning as a minority rural tourist destinations. The empowerment of the villages is being described by some authors as a community participation which is the other term commonly used when discussing the development of rural tourism (Bao \& Sun, 2008).

\section{Conclusion}

Both of the above-mentioned villages have similar characteristic and potential of rural tourism development. Using empowerment of the villages which has been used before in lots of cases of rural tourism these villages can develop better. Improve the economy of both village residents and the tourism industry and spread and conserve the local culture (Akama, 1996). Rural tourism can make the full use of natural and cultural resources possessed by these villages and it can optimize rural industrial structures which can be extended to agriculture, tourism services and what is also very important, increase the income of farmers and other village residents (Zhang, 2012). By using the so-called Langde Mode, modified to fit the villages of Zlot and Xiaocang, rural tourism in these villages can be improved largely.

The specific cultures these villages have are the main driving force which can attract both local and foreign tourists. Intangible cultural heritage is one of the driving forces in tourism offering tourists an opportunity to experience culture with its customs, rituals, beliefs, music, skills, crafts, oral literature and more. Minority cultures which can be experienced only in a limited number of places can offer a higher profitability of the tourism products of a certain destination (Filipović, 2018). The villages have a strong foundation for both rural and cultural tourism, which is the main way for cultural exchange, giving tourists experiences of the cultural and social life of the destination (Demirović et al., 2018). By using the intangible cultural heritage these minorities have, a strong brand image should be made in order to ensure good positioning of the tourist destination image (Blažević \& Chen, 2018). The limitations of this paper are that it still does not offer a definite strategy for developing tourism in these villages but it offers a good overview of the current situation of the villages and some of the positive strategies that can be used as an example. Possible future research should include practical use in the means of in-depth strategizing and giving some corrective measures which can be implemented to better the lives of the local community, give them a good platform for preserving their cultural heritage and offering it to the tourists, so they can understand it better.

\section{References}

1. Akama, J. S. (1996). Western environmental values and nature-based tourism in Kenya. Tourism Management, 17(8), 567-574. https://doi.org/10.1016/S02615177(96)00077-5

2. Balan, M., \& Burghelea, C. (2015). Rural tourism and its implication in the development of the Fundata Village. Procedia - Social and Behavioral Sciences, 188, 276-281. https://doi.org/10.1016/j.sbspro.2015.03.393 
3. Bao, J., \& Sun, J. (2008). Community participation in tourism of Yubeng village:Means of participation and its significance for empowerment. Tourism forum, 4, 58-65.

4. Blažević, M., \& Chen, G. (2018). Image of Fujian province as a tourist destination A foreginer's perspective. Facta Universitatis Series: Economics and Organization, 15(3), 257-270. https://doi.org/10.22190/FUEO1803257B

5. Chen, Z., Li, L., \& Li, T. (2016). The organizational evolution, systematic construction and empowerment of Langde Miao's community tourism. Tourism Management, 58, 276-285. https://doi.org/10.1016/j.tourman.2016.03.012

6. Demirović, D., Cimbaljević, M., \& Vujko, A. (2018). Religious sites and events as resources for tourism development in cities - case study: Novi Bečej. Hotel and Tourism Management, 6(1), 63-71. https://doi.org/10.5937/menhottur1801063D

7. Dimitrovski, D. D., Todorović, A. T., \& Valjarević, A. D. (2012). Rural tourism and regional development: Case study of development of rural tourism in the region of Gruža, Serbia. Procedia Environmental Sciences, 14, 288-297. https://doi.org/10.1016/j.proenv.2012.03.028

8. Filipović, N. (2018). Intangible cultural heritage as a motive for choosing the tourist destination Aranđelovac. Hotel and Tourism Management, 6(1), 53-62. https://doi.org/10.5937/menhottur1801053F

9. Gao, J., \& Wu, B. (2017). Revitalizing traditional villages through rural tourism: A case study of Yuanjia Village, Shaanxi Province, China. Tourism Management, 63, 223-233. https://doi.org/10.1016/j.tourman.2017.04.003

10. Guo, Z., \& Sun, L. (2016). The planning, development and management of tourism: The case of Dangjia, an ancient village in China. Tourism Management, 56, 52-62. https://doi.org/10.1016/j.tourman.2016.03.017

11. Ivkov-Džigurski, A., Babić, V., \& Dragin, A. (2012). The Mystery of Vlach Magic. Eastern European Countryside, 18, 61-83. https://doi.org/10.2478/v10130-012-00049

12. Nowicka, E. (2016). Ethnic Identity of Aromanians/Vlachs in the 21 st Century. Res Historica, 213-235. https://doi.org/10.17951/rh.2016.41.1.213

13. Silva, L., \& Lenar, J. (2015). Rural tourism and national identity building in contemporary Europe: Evidence from Portugal. Journal of Rural Studies, 38, 109119. https://doi.org/10.1016/j.jrurstud.2015.02.005

14. Trišić, I. (2017). Ethno-social tourist values of Branicevo District. Hotel and Tourism Management, 5(2), 51-60.

15. Zhang, X. (2012). Research on the developement strategies of rural tourism in Suzhou based on SWOT analysis. Energy Procedia, 16, 1295-1299. https://doi.org/10.1016/j.egypro.2012.01.207

16. Zuo, B. (2009). Localization of empowerment theory in China's tourism development: a case study of Diqing in Yunnan Province. Tourism Science, 23(2), 1-8. https://doi.org/10.16323/j.cnki.lykx.2009.02.003

Received: 8 November 2018; Sent for revision: 11 November 2018; Accepted: 26 November 2018 